\title{
Mechanical Properties of Geopolymers Synthesized from Fly Ash and Red Mud under Ambient Conditions
}

\author{
Nevin Koshy ${ }^{1,2, \dagger}$, Kunga Dondrob ${ }^{1,+}$, Liming Hu ${ }^{1, *(\mathbb{C})}$, Qingbo Wen ${ }^{1}$ and Jay N. Meegoda ${ }^{1,3}$ (i) \\ 1 State Key Laboratory of Hydro-Science and Engineering, Department of Hydraulic Engineering, \\ Tsinghua University, Beijing 100091, China; nevin.koshy@iitjammu.ac.in (N.K.); \\ kunga-dondrob@foxmail.com (K.D.); wenqb@tsinghua.edu.cn (Q.W.); meegoda@njit.edu (J.N.M.) \\ 2 Department of Civil Engineering, Indian Institute of Technology Jammu, Jammu and Kashmir 190006, India \\ 3 Department of Civil and Environmental Engineering, New Jersey Institute of Technology, Newark, \\ NJ 071021982, USA \\ * Correspondence: gehu@tsinghua.edu.cn; Tel.: +86-133-1132-0805 \\ + Joint first authors.
}

Received: 20 September 2019; Accepted: 30 October 2019; Published: 31 October 2019

check for updates

\begin{abstract}
Aluminosilicate gels form geopolymers and nanocrystalline zeolites which have comparable strength properties, making them a potential replacement for ordinary Portland cement. The study explores the use of two untreated industrial wastes, Class-F fly ash and red mud, for synthesizing geopolymeric material at ambient synthesis conditions. The high alkalinity present in the red mud was exploited for the dissolution of silica in the fly ash and red mud. The mechanical, mineralogical, microstructural, and pore characteristics were analyzed and the contributions of curing period, $\mathrm{Si} / \mathrm{Al}$, $\mathrm{Na} / \mathrm{Al}$, and liquid-to-solid (L/S) ratios on the compressive strength of the end products were also investigated. The alkalinity of the system due to the red mud was adequate for the dissolution of raw fly ash and the subsequent formation of aluminosilicate gels. The strength of the end product was directly proportional to the initial $\mathrm{Si} / \mathrm{Al}$ ratio and the specimens with highest fly ash content exhibited highest compressive strength values after 28 days of curing. Furthermore, fly ash contributed to the formation and distribution of interstitial and capillary pores in the aluminosilicate matrix. The lowest L/S ratio of the initial mix resulted in the end product with the highest unconfined compressive strength.
\end{abstract}

Keywords: fly ash; red mud; geopolymer; characterization; unconfined compressive strength

\section{Introduction}

With the rise in global environmental pollution, energy crisis, and depletion of mineral resources, there is a need for the reuse of industrial wastes such as fly ash and red mud [1,2]. Globally, around 780 million tons of fly ash and 150 million tons of red mud are annually generated, needing urgent utilization [2,3]. Fly ash, a coal combustion byproduct, contains significant amounts of Si and Al [4] and can be used as a raw material for the synthesis of aluminosilicate-based cementitious materials. Red mud, an industrial byproduct from bauxite processing, contains residual Al and iron oxide, along with a smaller concentration of silica [5]. Furthermore, red mud has very high pH ranging from 10-13, which makes it a promising source for maintaining high $\mathrm{pH}$ in alkali activation such as geopolymerization and zeolitization [6].

Aluminosilicate gels form geopolymers and nanocrystalline zeolites which have comparable strength properties, making them a potential replacement for ordinary Portland cement [7]. They have been synthesized using aluminosilicates and an alkali activator solution such as $\mathrm{Na}_{2} \mathrm{SiO}_{3}, \mathrm{NaOH}_{\text {, }}$ 
$\mathrm{Na}_{2} \mathrm{CO}_{3}$, and $\mathrm{KOH}$ [8-10]. These aluminosilicate compounds have found several applications in civil and environmental engineering, such as in cement [11,12], foamed panels [13], heavy metal immobilization [14], masonry units [15,16], paving blocks [17], and soil stabilization [18]. Several studies have been conducted by synthesizing these, using different precursors such as metakaolin [11,12,19-21] and industrial byproducts such as coal fly ash [22-24], coal gangue [25,26], slags [22], municipal solid waste incinerator fly ash [27], recycled asphalt pavement [28], red mud [21,24,29], rice husk ash [6,11], waste glass [16], and water treatment sludge [15]. The formation of geopolymers from aluminosilicate raw materials can be given by Equations (1) and (2) [30]. Zhang et al. [31] derived geopolymers from class $\mathrm{F}$ fly ash and red mud using sodium trisilicate and sodium hydroxide at ambient conditions and reported that the strength of the end products increased with prolonged curing up to 6 months, while preliminary curing at $100 \%$ relative humidity showed negligible strength improvement. It was reported that $5-20 \%$ red mud improved the compressive strength of fly ash based geopolymers activated with $6 \mathrm{M} \mathrm{NaOH}$ [17]. For equally proportioned fly ash-red mud based geopolymers prepared at lower $\mathrm{NaOH}$ concentrations, Class $\mathrm{C}$ fly ash showed higher strength when compared to that with Class F fly ash [32].

$$
\begin{aligned}
& n\left(\mathrm{Si}_{2} \mathrm{O}_{5}, \mathrm{Al}_{2} \mathrm{O}_{2}\right)+2 n \mathrm{SiO}_{2}+4 n \mathrm{H}_{2} \mathrm{O}+\mathrm{NaOH} / \mathrm{KOH} \rightarrow \mathrm{Na}^{+}, \mathrm{K}^{+}+n(\mathrm{OH})_{3}-\mathrm{Si}-\mathrm{O}-\mathrm{Al}^{-}-\mathrm{O}-\mathrm{Si}-(\mathrm{OH})_{3} \\
& \text { (Si-Al materials) } \\
& (\mathrm{OH})_{2} \\
& \text { (Geopolymer precursor) }
\end{aligned}
$$

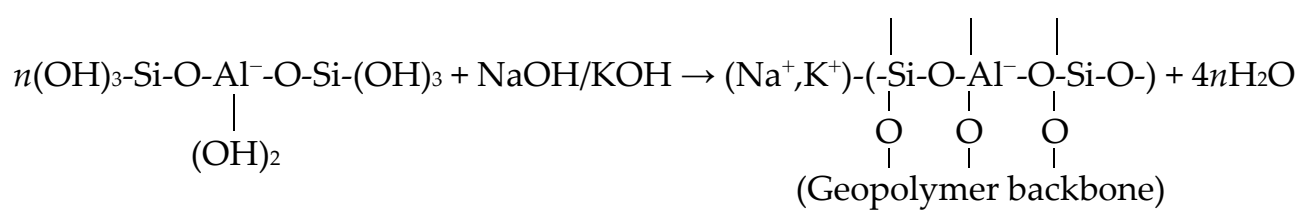

Many studies use commercial aluminosilicate compounds [9] such as metakaolin [12,19] and natural Si-Al minerals [8], as the partial or complete aluminosilicate sources for deriving geopolymers and cementitious binders $[9,21]$. Although some studies used industrial byproducts such as fly ash [13] and red mud [20,21], the use of additional alkali such as $\mathrm{NaOH}[17,31]$ makes the process less sustainable and adds to the cost of synthesis.

In the past, the pretreatment of raw materials have been attempted under higher temperatures (i.e., above room temperature) and by mechanical grinding [25]. Grinding the mixture of red mud and coal gangue before synthesis was reported to improve the surface area resulting in better compressive strength [25]. Nevertheless, these techniques are energy intensive and synthesis under ambient conditions of temperature and pressure without pretreatment would be an energy efficient solution [23]. Hence, this study explores the use of Class-F fly ash and red mud without any pretreatment for synthesis of low range geopolymeric end products at ambient conditions using the high alkalinity present in the red mud. Mercury intrusion porosimetry and scanning electron microscopy were used to determine the porosity and morphology of the synthesized aluminosilicates. Furthermore, the contribution of curing time, initial Si/Al and $\mathrm{Na} / \mathrm{Al}$ ratios of the mixtures and liquid to solid (L/S) ratio on the mechanical characteristics of the end products have also been investigated.

\section{Materials and Methods}

\subsection{Materials Used}

The fly ash used in the study was sourced from Zhangjiakou Power Plant, Hebei, China and the red mud was obtained from Zibo, Shandong, China. The fly ash and red mud were dried overnight at $105^{\circ} \mathrm{C}$ and their chemical compositions were determined using $\mathrm{X}$-ray fluorescence and are presented in Table 1. The loss on ignition was determined as per ASTM D 7348-08 [33] by heating the oven-dried 
sample in a muffle furnace (Zhonghuandianlu SX-G08133, Tianjin, China) to $500{ }^{\circ} \mathrm{C}$ for $1 \mathrm{~h}$ and $750{ }^{\circ} \mathrm{C}$ for $2 \mathrm{~h}$. The alkali activator, sodium silicate hydrate $\left(\mathrm{Na}_{2} \mathrm{SiO}_{3} \cdot 5 \mathrm{H}_{2} \mathrm{O}\right)$ was procured from Tianjin $\mathrm{Da}$ Mao chemical reagent factory, China.

Table 1. Chemical composition (wt $\%$ ) of fly ash and red mud.

\begin{tabular}{ccc}
\hline Composition & Fly Ash & Red Mud \\
\hline $\mathrm{SiO}_{2}$ & 45.79 & 8.88 \\
$\mathrm{Al}_{2} \mathrm{O}_{3}$ & 21.69 & 25.34 \\
$\mathrm{Na}_{2} \mathrm{O}$ & 0.46 & 8.75 \\
$\mathrm{CaO}$ & 7.07 & 0.92 \\
$\mathrm{Fe}_{2} \mathrm{O}_{3}$ & 6.68 & 40.03 \\
$\mathrm{TiO}_{2}$ & 1.47 & 6.49 \\
$\mathrm{SO}_{3}$ & 0.47 & 0.22 \\
$\mathrm{P}_{2} \mathrm{O}_{5}$ & 0.33 & 0.08 \\
$\mathrm{MnO}_{\mathrm{ZrO}}$ & 0.12 & 0.05 \\
$\mathrm{MgO}$ & 0.10 & 0.35 \\
$\mathrm{SrO}$ & 0.80 & - \\
$\mathrm{K}_{2} \mathrm{O}$ & 0.31 & - \\
$\mathrm{Cr}_{2} \mathrm{O}_{3}$ & - & 0.06 \\
Loss on ignition & - & 0.12 \\
\hline
\end{tabular}

\subsection{Experimental Procedure}

To obtain the required $\mathrm{Si} / \mathrm{Al}$ and $\mathrm{Na} / \mathrm{Al}$ ratios, an activator solution of laboratory grade sodium metasilicate pentahydrate $\left(\mathrm{Na}_{2} \mathrm{SiO}_{3} \cdot 5 \mathrm{H}_{2} \mathrm{O}\right)$ was prepared at different concentrations of $30 \%, 40 \%$, and $50 \%$ weight-to-weight ratios $(\mathrm{w} / \mathrm{w})$ using deionized water and allowed to cool to ambient temperature $\left(23^{\circ} \mathrm{C}\right)$. Subsequently, different proportions of oven-dried fly ash (FA) and red mud (RM) were added to the solution (Figure 1a-c) at liquid-to-solid (L/S) ratios based on preliminary studies (Table 2). The Si/Al and $\mathrm{Na} / \mathrm{Al}$ ratios were determined based on the $\mathrm{Si}, \mathrm{Al}$, and $\mathrm{Na}$ contents in the fly ash, red mud, and sodium metasilicate. Based on the preliminary results of FA4, FA6, and FA8 [10], the FA:RM ratio of 8:2 was found to yield the highest strength. Hence, the influence of other parameters, viz., L/S, Si/Al, and $\mathrm{Na} / \mathrm{Al}$ ratios, on the unconfined compressive strength (UCS) were studied based on this FA:RM ratio of 8:2, as shown in Table 2. The sample labels are suffixed with either the amount of $\mathrm{Na}_{2} \mathrm{SiO}_{3} \cdot 5 \mathrm{H}_{2} \mathrm{O}$ (in \%wt) used or with their corresponding $\mathrm{L} / \mathrm{S}$ ratios. The $\mathrm{L} / \mathrm{S}$ ratios, ranging from 0.35 to 0.6 , were selected, taking into account workability as the precursor. For the proportions of fly ash and red mud, $\mathrm{L} / \mathrm{S}<0.35$ makes the mixture very stiff, while $\mathrm{L} / \mathrm{S}>0.6$ results in a loose slurry which is extremely slow to solidify under the normal conditions of curing. The mixture was homogenized for at least $15 \mathrm{~min}$ using a mechanical stirrer to achieve adequate consistency and subsequently poured into well-greased molds $10 \mathrm{~cm}$ long and $4 \mathrm{~cm}$ in diameter, having an aspect ratio of 2.5 in order to minimize the end effects. The samples were prepared in triplicates and the molds were vibrated for $5 \mathrm{~min}$ using a vortex vibrator and covered with a vinyl sheet at the top to avoid evaporation. After curing at $23{ }^{\circ} \mathrm{C}$ and relative humidity $(\mathrm{RH})$ of $45-50 \%$ for 7 days, the specimens were dismantled from molds (Figure $1 \mathrm{~d}$ ) and cured for the remaining days as shown in Table 2. RH of $40 \%$ to $50 \%$ was found to be ideal, since previous studies have shown that at $\mathrm{RH}<40 \%$ the sample cracks, while at higher values (i.e., $>50 \%$ ), carbonation takes place, resulting in lower strength [31]. 

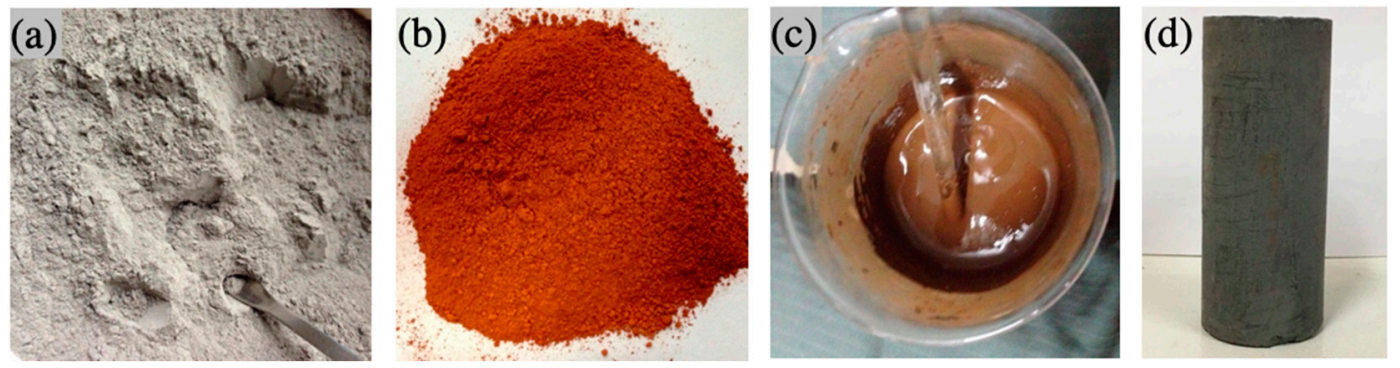

Figure 1. (a) Fly ash; (b) red mud used in the study; (c) prepared mixture; (d) cured unconfined compressive strength (UCS) specimen.

Table 2. Experimental details and proportions of ingredients.

\begin{tabular}{ccccccc}
\hline Label & Curing Time (days) & $\mathbf{F A} / \mathbf{R M}$ & $\mathbf{L} / \mathbf{S}$ & $\mathbf{N a}_{\mathbf{2}} \mathbf{S i O}_{\mathbf{3}} \cdot \mathbf{5} \mathbf{H}_{\mathbf{2}} \mathbf{O} \mathbf{( \% \mathbf { w t } )}$ & $\mathbf{S i} / \mathbf{A l}$ & $\mathbf{N a} / \mathbf{A l}$ \\
\hline FA4 & $7,14,21,28$ & $4: 6$ & 0.4 & $40 \%$ & 1.04 & 0.59 \\
FA6 & $7,14,21,28$ & $6: 4$ & 0.4 & $40 \%$ & 1.36 & 0.51 \\
FA8 & $7,14,21,28$ & $8: 2$ & 0.4 & $40 \%$ & 1.69 & 0.42 \\
FA8-30 & 7 & $8: 2$ & 0.4 & $30 \%$ & 1.65 & 0.35 \\
FA8-40 & 7 & $8: 2$ & 0.4 & $40 \%$ & 1.69 & 0.42 \\
FA8-50 & 7 & $8: 2$ & 0.4 & $50 \%$ & 1.74 & 0.50 \\
FA8-0.35 & 7 & $8: 2$ & 0.35 & $40 \%$ & 1.67 & 0.39 \\
FA8-0.4 & 7 & $8: 2$ & 0.4 & $40 \%$ & 1.69 & 0.42 \\
FA8-0.5 & 7 & $8: 2$ & 0.5 & $40 \%$ & 1.74 & 0.50 \\
FA8-0.6 & 7 & $8: 2$ & 0.6 & $40 \%$ & 1.78 & 0.57 \\
\hline
\end{tabular}

\subsection{Characterization}

The cured cylindrical specimens were tested for their UCS values using a standard UCS apparatus (VJ technology TRI-SCAN 50, Ashford, UK) at a constant loading rate of $0.5 \mathrm{~mm} \mathrm{~min}^{-1}$. The Young's Modulus $(E)$ was determined using the tangent/chord modulus of the stress-strain curve as per ASTM E111-17 [34]. The elemental composition of the raw materials was obtained using X-ray fluorescence (XRF, Shimadzu XRF-1800, Kyoto, Japan) and the mineralogical analysis of the dried and finely ground samples were conducted using an X-ray diffractometer (XRD, Rigaku SmartLab, Tokyo, Japan) with a Cu $K \alpha$ source. In order to understand the morphological and chemical characteristics of the end products, the failed UCS samples were studied using scanning electron microscopy (SEM) (Shimadzu SSX-550, Kyoto, Japan) fitted with energy dispersive spectroscopy (EDS). Pore characteristics were measured by employing the mercury intrusion porosimetry (MIP) (Quantachrome Poremaster, Ashland, USA). In order to obtain samples which are representative of the bulk, dried inner core samples were used for MIP instead of the external surfaces of the original specimens, which would have undergone high oxidation.

\section{Results and Discussion}

\subsection{Characterization of Fly Ash and Red Mud}

The chemical composition of the fly ash and red mud are shown in Table 1 and the fly ash was Class $\mathrm{F}$ as per ASTM C618-15 [35]. The red mud was composed of mainly $\mathrm{Fe}_{2} \mathrm{O}_{3}$ and $\mathrm{Al}_{2} \mathrm{O}_{3}$ and had an initial $\mathrm{pH}=12$. It should be noted that, since some portion of the silica and alumina in the mixture such as quartz and mullite are unreactive, only the amorphous phase of silica and alumina take part in the reaction $[20,36]$. In addition, the low calcium content of the initial mixture ( 3.9 to $6.7 \% \mathrm{CaO})$ is favorable for synthesis of geopolymers and could also show higher thermal stability [37].

\subsection{Pore Characteristics}

The development of the pore structure for the different FA:RM proportions after 28 days of curing characterized using MIP is presented in Figure 2 and Table 3. MIP can assess the pore size ranging from 
few nanometers to several hundred micrometers but has limitations, such as the "ink-bottle" effect and possible damage to existing pore structures due to the mercury intrusion. However, in spite of these limitations, MIP may yield sufficiently accurate porosity and pore sizes [12,13]. The pores in the end products can be classified into three types, (i) interstitial pores in the aluminosilicate gels (mesopores which range from $2 \mathrm{~nm}$ to $50 \mathrm{~nm}$ ), (ii) capillary pores (ranging from $10 \mathrm{~nm}$ to $1 \mu \mathrm{m}$ ), and (iii) air voids and hollow fly ash spherule voids ( $\geq 1 \mu \mathrm{m})$ [12]. From Table 3, it can be observed that the micro and mesopores (pore size $\leq 50 \mathrm{~nm}$ ), typical of geopolymeric gels, is highest for FA8. Incidentally, FA8 has the highest initial $\mathrm{Si} / \mathrm{Al}$ ratio and the least $\mathrm{Na} / \mathrm{Al}$ ratio. All three show pores at $200 \mu \mathrm{m}$ revealing the presence of air bubbles, with FA4 showing the highest value.
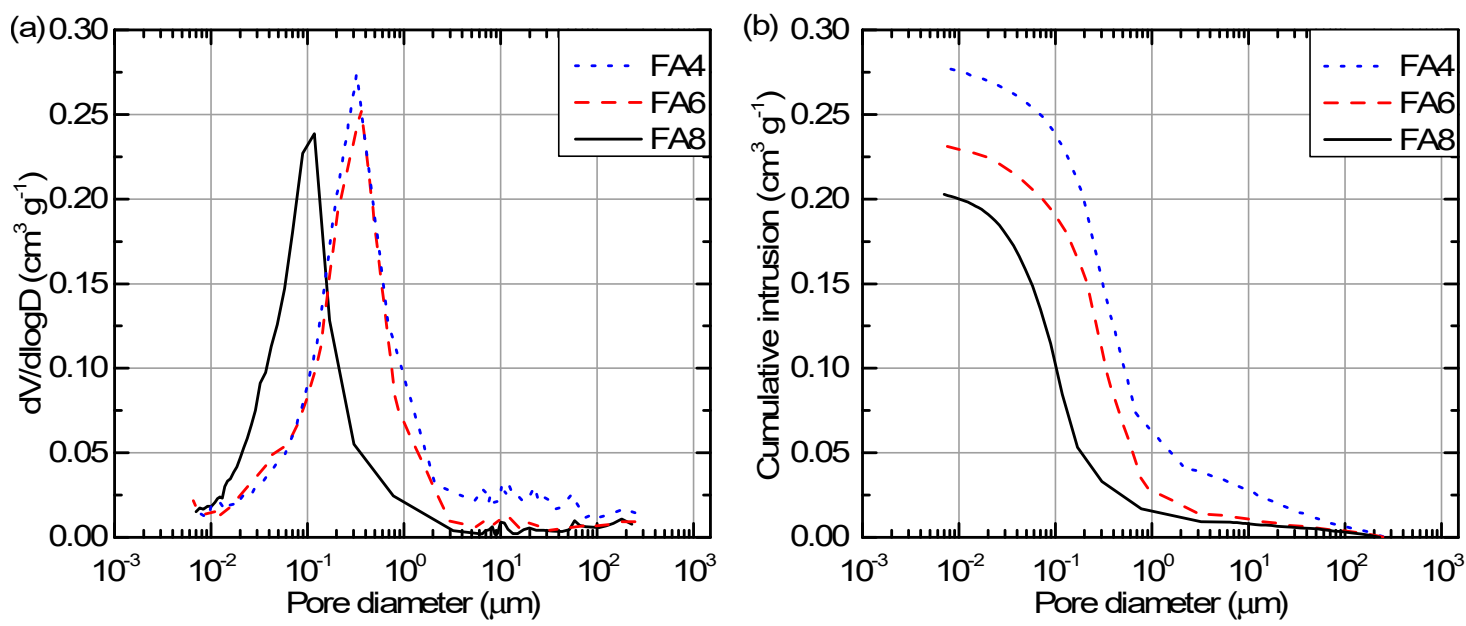

Figure 2. Mercury intrusion porosimetry (MIP) results of the end products indicating the pore size distribution based on (a) differential pore volume, $\mathrm{d} V / \mathrm{d} \log D ;(\mathbf{b})$ cumulative pore volume.

Table 3. Pore size distribution (\%) and strength of the end products after 28 days curing.

\begin{tabular}{|c|c|c|c|c|c|c|c|c|c|}
\hline \multirow{2}{*}{ Sample } & \multicolumn{6}{|c|}{ Pore Volume Contribution (\%) of Various Sizes (nm) } & \multirow{2}{*}{ Micro/Mesopores } & \multirow{2}{*}{ Macro Pores } & \multirow{2}{*}{ UCS (MPa) } \\
\hline & $<10$ & $10-50$ & $50-100$ & 100-200 & 200-1000 & $>1000$ & & & \\
\hline FA4 & 0.91 & 7.86 & 9.01 & 30.05 & 37.09 & 15.08 & 8.77 & 91.23 & 0.89 \\
\hline FA6 & 1.27 & 8.87 & 12.93 & 10.92 & 59.89 & 6.12 & 10.14 & 89.86 & 3.44 \\
\hline FA8 & 1.56 & 25.3 & 31.6 & 25.33 & 11.68 & 4.53 & 26.86 & 73.14 & 6.19 \\
\hline
\end{tabular}

A roughly similar pore distribution is seen for FA4 and FA6 with pores ranging from 10 to $50 \mathrm{~nm}$ (Figure 2a). Although the total macropores (i.e., pore size $>50 \mathrm{~nm}$ ) in all the systems only have a standard deviation of 10 , the pore size distribution within this range varies significantly, which could be a contributing factor to the variation in strength. Also, the lowest pore volume of $0.2 \mathrm{~cm}^{3} / \mathrm{g}$ for FA8 should produce the strongest material. This specimen, which has the highest UCS value, possesses the least amount of pores $\geq 200 \mathrm{~nm}$, while having the largest contribution of pores $\leq 100 \mathrm{~nm}$. The gel phase, which is developed under higher $\mathrm{Si} / \mathrm{Al}$ ratio, facilitates the formation of a compact microstructure. Hence, minimizing the development of macropores could help yield better strength under similar synthesis conditions.

\subsection{Microstructural and Mineralogical Characteristics}

For the sake of brevity, the scanning electron micrographs of only FA8, the specimen with highest UCS values, at different curing periods are shown in Figure 3. The minerals are identified using EDS and XRD results. However, it should be noted that, considering the heterogeneity in particle sizes of fly ash and red mud and the microstructural variations of the end products, SEM images and EDS results may not be representative of the bulk. After 7 days of curing (refer Figure 3a), spherical and loosely bound fly ash particles can be observed seated in precipitates and geopolymeric gels formed 
around them. The alkalinity in the red mud is sufficient for starting the geopolymeric reaction, but not adequate for ensuring complete dissolution of the fly ash particles. The interface between the spherical fly ash and the matrix is a weak zone which is susceptible to dislocation (Figure 3a) and cracking (Figure 3c).
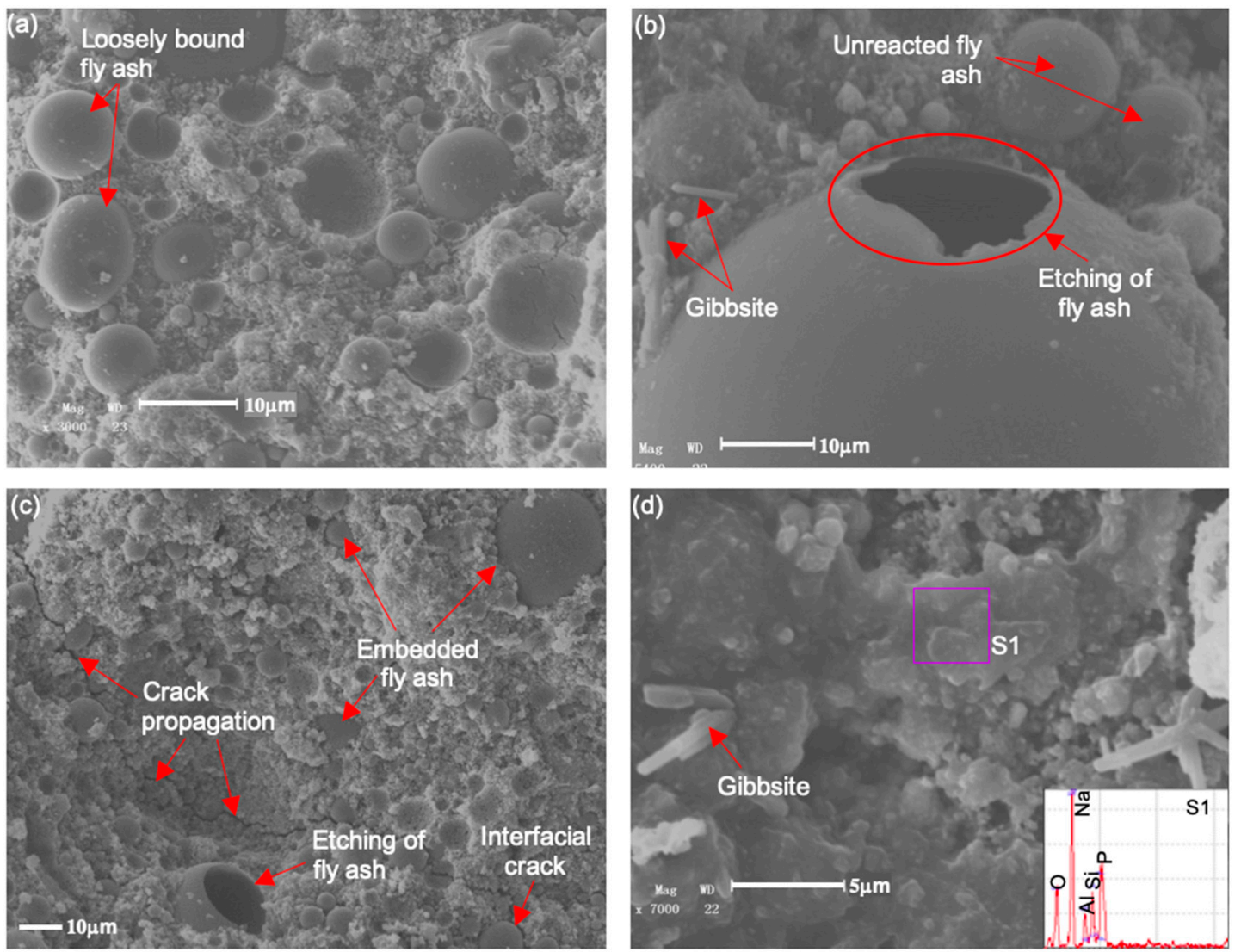

Figure 3. Microstructural characteristics of FA8 cured for (a) 7 days; (b) 14 days; (c) 21 days; (d) 28 days.

As the reaction progresses, the fly ash particles get etched due to the strong alkaline environment (Figure $3 b, c$ ) and the silica and alumina dissolve into the matrix and form geopolymers, silicate hydrates, or zeolites [36,38]. This etching can be observed from Figure 3b, showing a partially broken cenosphere, i.e., a hollow fly ash particle. From Figure $3 b, c$, it is clear that not all fly ash particles have undergone partial/full dissolution, possibly due to insufficient alkalinity. However, the unreacted mineral particles act as fillers resulting in varied mechanical characteristics [31].

Due to the evaporation of water, shrinkage cracks developed after 21 days (see Figure 3c) and they appear either in the precipitates/gels or at the fly ash-aluminosilicate gel interface. At the end of 28 days, the fly ash particles are deeply embedded in the solid matrix in contrast to the loosely held arrangement after 7 days (see Figure $3 \mathrm{~d}$ ). The EDS spectrum shows $\mathrm{Si} / \mathrm{Al}=1.6$, which is known to yield high strength in the case of pure metakaolin based geopolymers [39]. Furthermore, the high $\mathrm{Na} / \mathrm{Al}$ ratio of 4.8 also results in higher geopolymerization [31].

Figure 4 shows the X-ray diffractograms of the source materials and FA8, and the XRD peaks of the end products show similar trends in mineralogical crystallization and/or alterations for all three initial proportions of FA:RM. It has been pointed out in previous studies that the raw materials with lower crystallinity (or higher amorphous phase) are conducive for obtaining higher compressive strength $[8,20]$. There are no observable humps in the diffractograms of the end products unlike the characteristic amorphous silica (glassy phase) humps in raw fly ash around $25^{\circ}$. This could be due to several reasons: (i) the glassy phase of silica participates in the chemical reactions and hence its hump reduces, (ii) the amorphous humps of red mud and geopolymers are very broad [27,40], and (iii) there 
is an increased proportion of other crystalline and amorphous phases contributed by the red mud and also by the geopolymeric reactions.

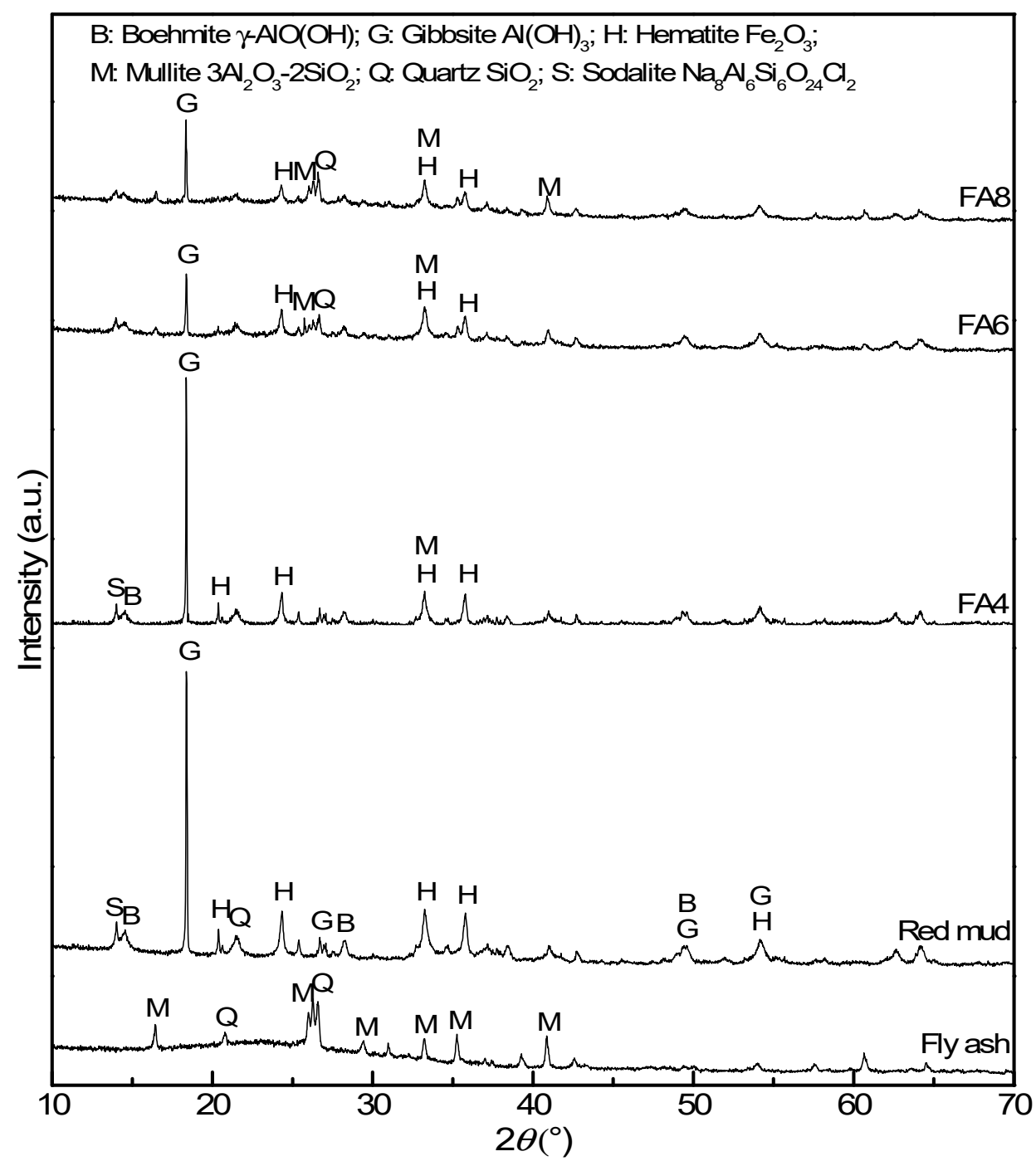

Figure 4. X-ray diffractograms of fly ash, red mud, and three geopolymers after 28 days.

The quartz and mullite, which were present in the raw fly ash, do not appear to lose much of their peak intensities upon activation of the aluminosilicates, which has also been reported in previous studies using pure or virgin products and red mud/coal gangue based geopolymers [25,40]. Mullite, an aluminosilicate mineral, is predominantly unreactive in alkaline medium as seen in FA8, the specimen with the highest fly ash content, by its visible peak at $26.2^{\circ}$. Gibbsite and boehmite, the aluminum hydroxide minerals originally present in bauxite, as well as hematite, are clearly visible in the XRD pattern of red mud. These non-reactive crystalline phases could negatively affect the strength development of the end products as inferred from the low strength of FA4 containing $60 \%$ red mud. However, upon activation in alkaline environment, the crystalline phase of some of these residual minerals decreases as inferred from the weakened intensities of their characteristic high-intensity peaks at $18.2^{\circ}$ for gibbsite and $14.4^{\circ}$ for boehmite. Incidentally, no apparent zeolite peaks were identified because of the low reaction temperatures, indicating that the reactions led only to geopolymeric gels, $\mathrm{N}-\mathrm{A}-\mathrm{S}-\mathrm{H}, \mathrm{C}-\mathrm{S}-\mathrm{H}$ gels, low-order aluminosilicate minerals, and/or precipitates. 


\subsection{Parametric Influences on Mechanical Properties}

The UCS results for the different fly ash-red mud proportions and curing periods are plotted in Figure 5. The initial concave portion in some of the curves is due to the artificial stiffening of the uneven end surfaces of the specimens, which disappear on application of adequate seating loads. In general, a well-defined elastic regime is noted for all samples, although the failure yielding is not well-defined. There is higher early strength development with increase in fly ash content and/or higher $\mathrm{Si} / \mathrm{Al}$ ratio. Furthermore, there is significant strength development after 28 days, i.e., 61, 69, and 62\% increase as compared to the 7 days strength for FA4, FA6, and FA8, respectively. The maximum value of compressive strength obtained, $6.61 \mathrm{MPa}$ for FA0.35, is slightly greater than the reported maximum of $5.84 \mathrm{MPa}$ for red mud-metakaolin based geopolymers [5]. Hence, the mixture is a viable alternative to using commercial metakaolin for aluminosilicate activation for strength development.
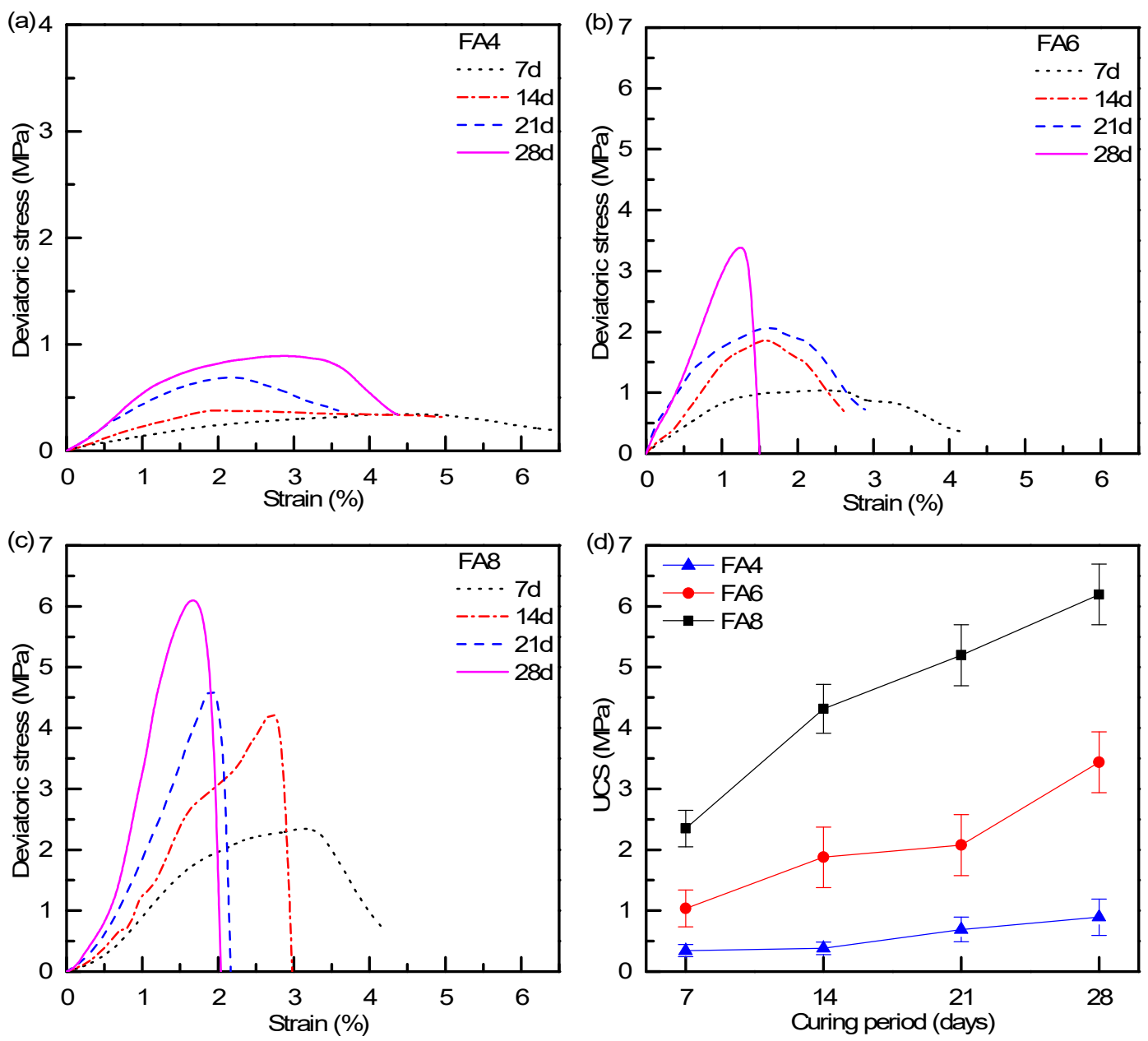

Figure 5. The stress-strain curves of (a) FA4; (b) FA6; and (c) FA8; and (d) the unconfined compressive strength at different curing periods.

The stiffness (i.e., the Young's modulus, E) of the specimens also improved with increase in the curing period and fly ash content as seen from $E=0.06,0.34$, and $0.63 \mathrm{GPa}$ at 28 days curing for FA4, FA6, and FA8 respectively (see Table 4). This improvement in strength is due to moisture loss and/or additional chemical reactions [28]. For high red mud content in the samples, i.e., 60\% RM in FA4, a ductile failure occurs (see Figure 5a) and the failure mechanism transitions from ductile to brittle with increase in fly ash content (see Figure $5 b, c$ ). Higher red mud content results in lower compressive strengths because of lower reactive silica and alumina content as well as the development of ductile behavior (refer Figure 5) imparted by the fine red mud particles [29]. Similarly, an increase in the 
curing period also changes the failure mode from ductile to brittle, perhaps due to the formation of micro cracks. Clearly, the mechanical properties are time-dependent, which is similar to previous studies using metakaolin, fly ash, red mud, and rice husk based geopolymers [20,41]. From Figure 5d, it is noted that even at 28 days of curing, the strength shows an upward trend without reaching a plateau indicating that complete curing has not been achieved, and hence, a prolonged curing beyond 28 days would further improve the strength and stiffness. This gradual strength development could be due to the presence of lime in the mixture (i.e., 3.9, 5.3, and 6.7\% for FA4, FA6, and FA8, respectively), thereby requiring prolonged curing [18].

Table 4. Unconfined compressive strength (UCS) and Young's Modulus (E) for the geopolymers at different curing periods.

\begin{tabular}{ccc}
\hline Sample & UCS (MPa) & E (GPa) \\
\hline FA4-7d & 0.34 & 0.01 \\
FA4-14d & 0.38 & 0.03 \\
FA4-21d & 0.69 & 0.05 \\
FA4-28d & 0.89 & 0.06 \\
FA6-7d & 1.03 & 0.08 \\
FA6-14d & 1.88 & 0.18 \\
FA6-21d & 2.08 & 0.19 \\
FA6-28d & 3.44 & 0.34 \\
FA8-7d & 2.35 & 0.15 \\
FA8-14d & 4.32 & 0.27 \\
FA8-21d & 5.20 & 0.32 \\
FA8-28d & 6.19 & 0.63 \\
FA30 & 0.53 & 0.07 \\
FA40 & 2.35 & 0.15 \\
FA50 & 3.61 & 0.24 \\
FA0.35 & 6.61 & 0.38 \\
FA0.4 & 6.19 & 0.15 \\
FA0.5 & 1.96 & 0.10 \\
FA0.6 & 1.84 & 0.10 \\
\hline
\end{tabular}

Figure 6 shows the influence of initial Si/Al and $\mathrm{Na} / \mathrm{Al}$ ratios in the final strength of the activated end products. Their strength increases with increase in the initial Si/Al and with decrease in the $\mathrm{Na} / \mathrm{Al}$. A higher $\mathrm{Na}$ content when compared to $\mathrm{Al}$ and $\mathrm{Si}$ would result in the formation of $\mathrm{Na}$ salts or zeolites which would lead to lower mechanical strengths [42]. For 28 days' strength, straight line fits with positive and negative slopes are obtained for $\mathrm{Si} / \mathrm{Al}$ and $\mathrm{Na} / \mathrm{Al}$ plots, respectively. However, further curing may have different patterns of strength as in the case of pure geopolymers where a gradual rise in $\mathrm{Si} / \mathrm{Al}$ and a sudden subsequent fall has been reported [40]. The trends of the variation of Young's modulus with $\mathrm{Si} / \mathrm{Al}$ and $\mathrm{Na} / \mathrm{Al}$ ratios are similar to those of UCS. The sustainably synthesized geopolymers from this study have adequate strength to be utilized as a sustainable road base material [43] and in soil stabilization [18]. 
(a) 7
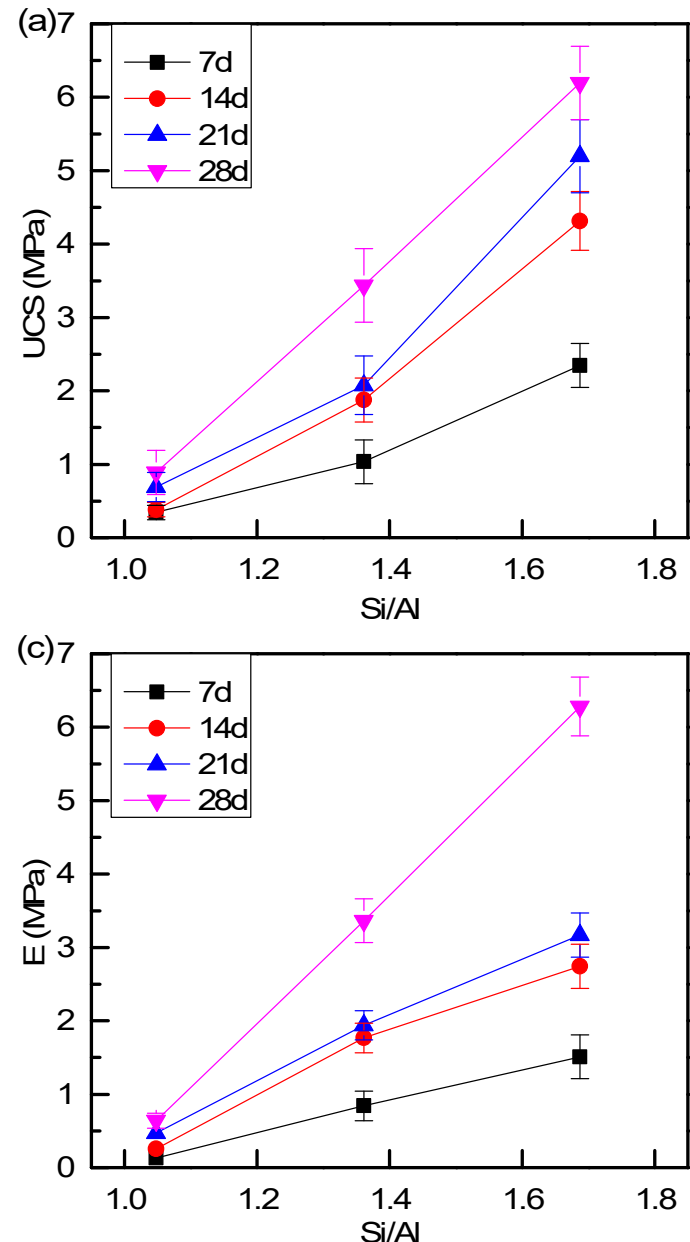

(b) 7

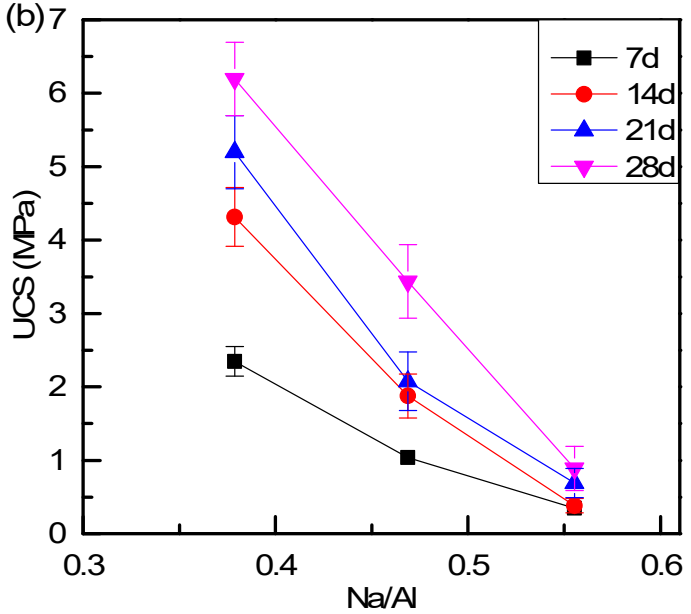

(d) 7

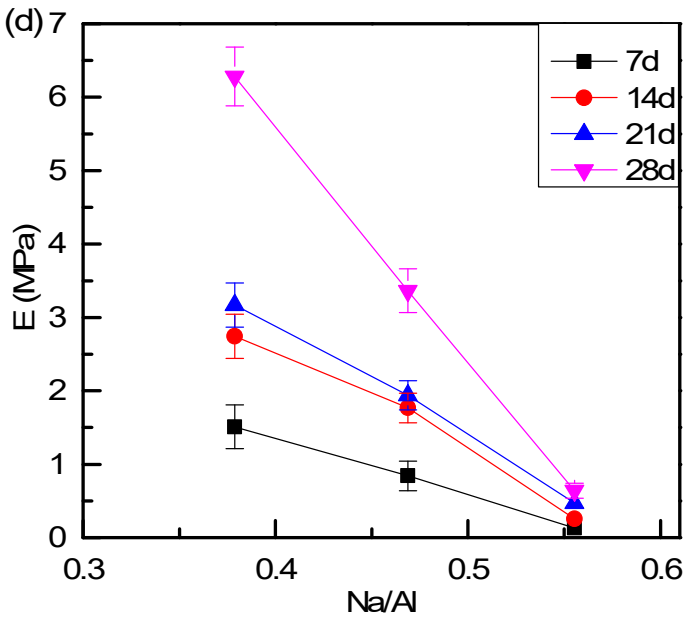

Figure 6. The unconfined compressive strength of the end products at different (a) $\mathrm{Si} / \mathrm{Al}$ and (b) $\mathrm{Na} / \mathrm{Al}$ ratios; and the Young's modulus $(E)$ at different (c) $\mathrm{Si} / \mathrm{Al}$ and $(\mathbf{d}) \mathrm{Na} / \mathrm{Al}$ ratios.

The influence of $\mathrm{L} / \mathrm{S}$ ratios on the UCS was studied using FA:RM ratio of 8:2 with $\mathrm{L} / \mathrm{S}$ ranging from 0.35 to $0.6 \mathrm{w} / \mathrm{w}$ and the strength results are presented in Figure 7 . The minimum $\mathrm{L} / \mathrm{S}$ was chosen as 0.35 , below which, the mixture becomes very stiff and is not workable. As seen in Figure $7 \mathrm{~b}$, the strength increased exponentially with decrease in the liquid to solid (L/S) ratio, while the UCS values improved significantly (UCS $=6.6 \mathrm{MPa}$ at $\mathrm{L} / \mathrm{S}$ of 0.35 ). This observation corroborates with previous studies using other geopolymers where minimal water content (i.e., just adequate for workability) should be maintained to obtain the best strength values. Park et al. [44] showed an exponential relationship between the mechanical properties and porosity of ceramic geopolymers. This is due to the fact that the drier the precursor, the lesser the porosity, resulting in better mechanical characteristics in the synthesized geopolymer [45]. 

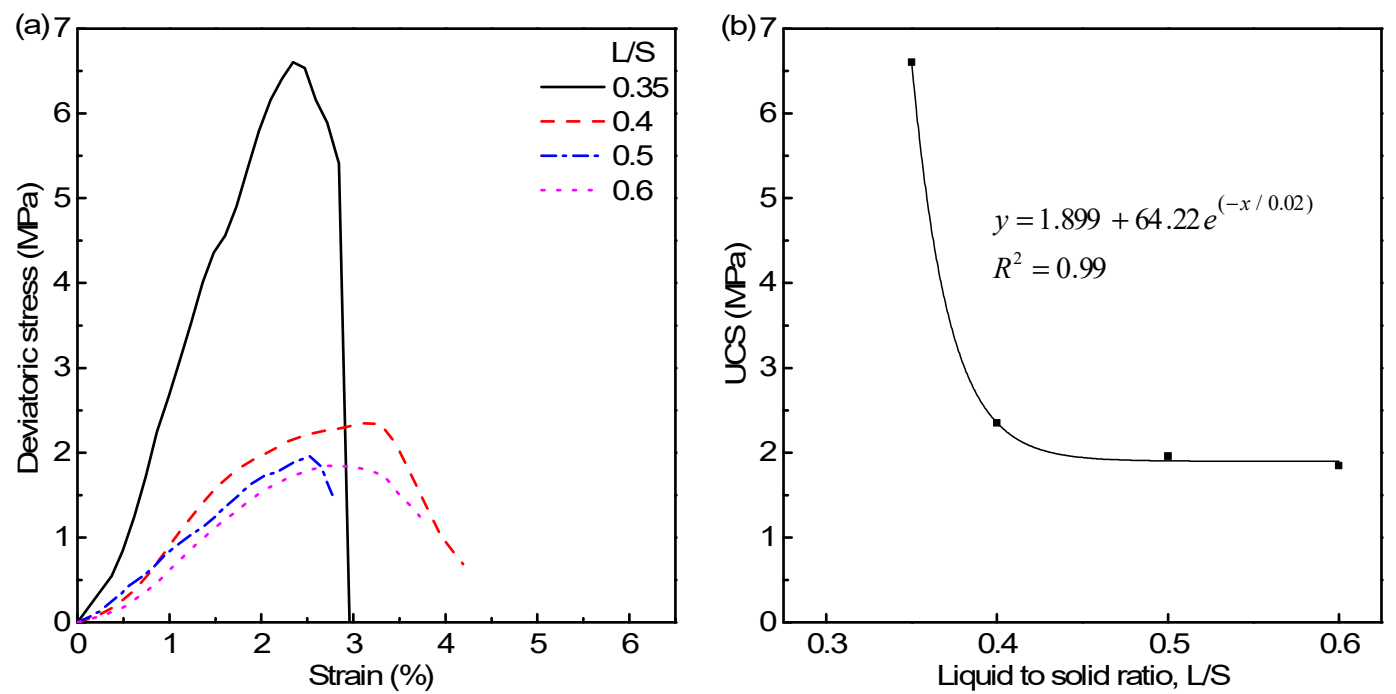

Figure 7. (a) Stress-strain curves of the end products at various liquid to solid (L/S) ratios; (b) the relationship between unconfined compressive strength (UCS) and L/S ratio after 7 days curing.

In this manuscript, the geopolymers synthesized from fly ash and red mud under ambient conditions can be termed Controlled Low-Strength Material (CLSM). The CLSM is used in various construction applications including temporary construction, structural backfilling, utility bedding, and void filling.

\section{Conclusions}

This study examined the feasibility of synthesizing geopolymers from coal fly ash and red mud at ambient laboratory conditions. The following are the main conclusions from the study:

- Geopolymers can be sustainably synthesized by utilizing the high alkalinity of red mud without the introduction of commercial hydroxides.

- The inherent alkalinity of the red mud results in partial dissolution of the aluminosilicates in the raw fly ash and subsequent formation of aluminosilicate gels.

- The strength of the end products synthesized under ambient conditions using fly ash and red mud, without the addition of alkali such as $\mathrm{NaOH}$, continues to increase significantly from 7 to 28 days with UCS $=6.19 \mathrm{MPa}$ for FA8 after 28 days.

- The stiffness increases with the increase in the curing time and there is a transition from ductile to brittle behavior with the increase in both fly ash content as well as curing time. For the same synthesis conditions, a higher quantity of fly ash with same amount of red mud yields better strength and stiffness values as seen by $E=0.63 \mathrm{GPa}$ at 28 days for FA8.

- The amount of fly ash affects the formation and distribution of various types of pores in the geopolymeric matrix, wherein a high starting $\mathrm{Si} / \mathrm{Al}$ ratio gives rise to interstitial pores in the final geopolymeric matrix. For a curing period of 7 days, the end product showed $6.6 \mathrm{MPa}$ at $\mathrm{L} / \mathrm{S}$ of 0.35 .

- The unconfined compressive strength of the end products and the L/S ratio follow an inverse exponential relationship similar to the porosity characteristics, and the minimum L/S ratio of 0.35 was found to be optimum for obtaining higher strength fly ash-red mud based aluminosiliceous materials with lesser porosity.

Author Contributions: Conceptualization, L.H. and Q.W.; methodology, L.H. and Q.W.; formal analysis, K.D. and N.K.; investigation, K.D.; resources, L.H. and Q.W.; data curation, N.K.; writing-original draft preparation, N.K.; writing-review and editing, L.H. and J.N.M.; visualization, N.K.; supervision, L.H., Q.W. and J.N.M.; project administration, L.H.; funding acquisition, L.H. The first two authors equally contributed to this paper. 
Funding: This research was funded by National Natural Science Foundation of China (Project No. 51979144 and 51323014), Tsinghua University (Project No. 2015THZ02-2-20161080101 and 2015THZ01-1-20161080079) and State Key Laboratory of Hydro-Science and Engineering (Open Research Fund Program 2019-D-03).

Acknowledgments: The authors would like to acknowledge the State Key Laboratory of Hydro-Science and Engineering for providing the testing facilities.

Conflicts of Interest: The authors declare no conflict of interest. The funders had no role in the design of the study; in the collection, analyses, or interpretation of data; in the writing of the manuscript, or in the decision to publish the results.

\section{References}

1. Koshy, N.; Singh, D.N. Fly ash zeolites for water treatment applications. J. Environ. Chem. Eng. 2016, 4, 1460-1472. [CrossRef]

2. Toniolo, N.; Boccaccini, A.R. Fly ash-based geopolymers containing added silicate waste. A review. Ceram. Int. 2017, 43, 14545-14551. [CrossRef]

3. Evans, K. The History, Challenges, and New Developments in the Management and Use of Bauxite Residue. J. Sustain. Metall. 2016, 2, 316-331. [CrossRef]

4. Koshy, N.; Jha, B.; Kadali, S.; Singh, D.N. Synthesis and Characterization of Ca and Na Zeolites (Non-Pozzolanic Materials) Obtained From Fly Ash-Ca(OH $)_{2}$ Interaction. Mater. Perform. Charact. 2015, 4, 87-102.

5. Ascensão, G.; Seabra, M.P.; Aguiar, J.B.; Labrincha, J.A. Red mud-based geopolymers with tailored alkali diffusion properties and $\mathrm{pH}$ buffering ability. J. Clean. Prod. 2017, 148, 23-30. [CrossRef]

6. He, J.; Jie, Y.; Zhang, J.; Yu, Y.; Zhang, G. Synthesis and characterization of red mud and rice husk ash-based geopolymer composites. Cem. Concr. Compos. 2013, 37, 108-118. [CrossRef]

7. Provis, J.L.; Lukey, G.C.; Van Deventer, J.S.J. Do geopolymers actually contain nanocrystalline zeolites? A reexamination of existing results. Chem. Mater. 2005, 17, 3075-3085. [CrossRef]

8. Xu, H.; Van Deventer, J.S.J. Geopolymerisation of multiple minerals. Miner. Eng. 2002, 15, 1131-1139. [CrossRef]

9. Juenger, M.C.G.; Winnefeld, F.; Provis, J.L.; Ideker, J.H. Advances in alternative cementitious binders. Cem. Concr. Res. 2011, 41, 1232-1243. [CrossRef]

10. Koshy, N.; Dondrob, K.; Hu, L.; Wen, Q.; Meegoda, J.N. Synthesis and characterization of geopolymers derived from coal gangue, fly ash and red mud. Constr. Build. Mater. 2019, 206, 287-296. [CrossRef]

11. Kamseu, E.; Beleuk à Moungam, L.M.; Cannio, M.; Billong, N.; Chaysuwan, D.; Melo, U.C.; Leonelli, C. Substitution of sodium silicate with rice husk ash- $\mathrm{NaOH}$ solution in metakaolin based geopolymer cement concerning reduction in global warming. J. Clean. Prod. 2017, 142, 3050-3060. [CrossRef]

12. Yang, T.; Zhu, H.; Zhang, Z. Influence of fly ash on the pore structure and shrinkage characteristics of metakaolin-based geopolymer pastes and mortars. Constr. Build. Mater. 2017, 153, 284-293. [CrossRef]

13. Ducman, V.; Korat, L. Characterization of geopolymer fly-ash based foams obtained with the addition of Al powder or $\mathrm{H}_{2} \mathrm{O}_{2}$ as foaming agents. Mater. Charact. 2016, 113, 207-213. [CrossRef]

14. Guo, X.; Zhang, L.; Huang, J.; Shi, H. Detoxification and solidification of heavy metal of chromium using fly ash-based geopolymer with chemical agents. Constr. Build. Mater. 2017, 151, 394-404. [CrossRef]

15. Suksiripattanapong, C.; Horpibulsuk, S.; Boongrasan, S.; Udomchai, A. Unit weight, strength and microstructure of a water treatment sludge-Fly ash lightweight cellular geopolymer. Constr. Build. Mater. 2015, 94, 807-816. [CrossRef]

16. Arulrajah, A.; Kua, T.-A.; Horpibulsuk, S.; Phetchuay, C. Strength and microstructure evaluation of recycled glass-fly ash geopolymer as low-carbon masonry units. Constr. Build. Mater. 2016, 114, 400-406. [CrossRef]

17. Kumar, A.; Kumar, S. Development of paving blocks from synergistic use of red mud and fly ash using geopolymerization. Constr. Build. Mater. 2013, 38, 865-871. [CrossRef]

18. Zhang, M.; Zhao, M.; Zhang, G.; Nowak, P.; Coen, A.; Tao, M. Calcium-free geopolymer as a stabilizer for sulfate-rich soils. Appl. Clay Sci. 2015, 108, 199-207. [CrossRef]

19. Rowles, M.; O'Connor, B. Chemical optimisation of the compressive strength of aluminosilicate geopolymers synthesised by sodium silicate activation of metakaolinite. J. Mater. Chem. 2003, 13, 1161-1165. [CrossRef] 
20. He, J.; Zhang, J.; Yu, Y.; Zhang, G. The strength and microstructure of two geopolymers derived from metakaolin and red mud-fly ash admixture: A comparative study. Constr. Build. Mater. 2012, 30, 80-91. [CrossRef]

21. Hajjaji, W.; Andrejkovičová, S.; Zanelli, C.; Alshaaer, M.; Dondi, M.; Labrincha, J.A.; Rocha, F. Composition and technological properties of geopolymers based on metakaolin and red mud. Mater. Des. 2013, 52, 648-654. [CrossRef]

22. Izquierdo, M.; Querol, X.; Davidovits, J.; Antenucci, D.; Nugteren, H.; Fernández-Pereira, C. Coal fly ash-slag-based geopolymers: Microstructure and metal leaching. J. Hazard. Mater. 2009, 166, 561-566. [CrossRef] [PubMed]

23. Zhuang, X.Y.; Chen, L.; Komarneni, S.; Zhou, C.H.; Tong, D.S.; Yang, H.M.; Yu, W.H.; Wang, H. Fly ash-based geopolymer: Clean production, properties and applications. J. Clean. Prod. 2016, 125, 253-267. [CrossRef]

24. Zhang, M.; Zhao, M.; Zhang, G.; Mann, D.; Lumsden, K.; Tao, M. Durability of red mud-fly ash based geopolymer and leaching behavior of heavy metals in sulfuric acid solutions and deionized water. Constr. Build. Mater. 2016, 124, 373-382. [CrossRef]

25. Geng, J.J.; Zhou, M.; Li, Y.; Chen, Y.; Han, Y.; Wan, S.; Zhou, X.; Hou, H. Comparison of red mud and coal gangue blended geopolymers synthesized through thermal activation and mechanical grinding preactivation. Constr. Build. Mater. 2017, 153, 185-192. [CrossRef]

26. Dondrob, K.; Koshy, N.; Wen, Q.; Hu, L. Synthesis and Characterization of Geopolymers from Coal Gangue, Fly Ash and Red Mud. In The International Congress on Environmental Geotechnics; Springer: Berlin/Heidelberg, Germany, 2018; pp. 420-427.

27. Ye, N.; Yang, J.; Liang, S.; Hu, Y.; Hu, J.; Xiao, B.; Huang, Q. Synthesis and strength optimization of one-part geopolymer based on red mud. Constr. Build. Mater. 2016, 111, 317-325. [CrossRef]

28. Hoy, M.; Horpibulsuk, S.; Rachan, R.; Chinkulkijniwat, A.; Arulrajah, A. Recycled asphalt pavement-Fly ash geopolymers as a sustainable pavement base material: Strength and toxic leaching investigations. Sci. Total Environ. 2016, 573, 19-26. [CrossRef]

29. Zhang, G.; He, J.; Gambrell, R. Synthesis, Characterization, and Mechanical Properties of Red Mud-Based Geopolymers. Transp. Res. Rec. 2010, 2167, 1-9. [CrossRef]

30. Davidovits, J. Geopolymers: Inorganic polymeric new materials. J. Therm. Anal. 1991, 37, $1633-1656$. [CrossRef]

31. Zhang, M.; El-Korchi, T.; Zhang, G.; Liang, J.; Tao, M. Synthesis factors affecting mechanical properties, microstructure, and chemical composition of red mud-fly ash based geopolymers. Fuel 2014, 134, 315-325. [CrossRef]

32. Hu, W.; Nie, Q.; Huang, B.; Shu, X.; He, Q. Mechanical and Microstructural Characterization of Geopolymers Derived from Red Mud and Fly Ashes. J. Clean. Prod. 2018, 186, 799-806. [CrossRef]

33. ASTM. Standard Test Methods for Loss on Ignition (LOI) of Solid Combustion. In Annual Book of ASTM Standards; ASTM International: West Conshohocken, PA, USA, 2008; Volume D7348-08.

34. ASTM. Standard Test Method for Young's Modulus, Tangent Modulus, and Chord Modulus. In Annual Book of ASTM Standards; ASTM International: West Conshohocken, PA, USA, 2017; Volume E111-17, pp. 1-7.

35. ASTM. Standard Specification for Coal Fly Ash and Raw or Calcined Natural Pozzolan for Use in Concrete. In Annual Book of ASTM Standards; ASTM International: West Conshohocken, PA, USA, 2015; Volume C618-15, pp. 3-6.

36. Koshy, N.; Singh, D.N.; Jha, B.; Kadali, S.; Patil, J. Characterization of Na and Ca zeolites synthesized by various hydrothermal treatments of fly ash. Adv. Civ. Eng. Mater. 2015, 4, 131-143. [CrossRef]

37. Van Deventer, J.S.J.; Provis, J.L.; Duxson, P.; Brice, D.G. Chemical research and climate change as drivers in the commercial adoption of alkali activated materials. Waste Biomass Valorization 2010, 1, 145-155. [CrossRef]

38. Koshy, N.; Singh, D.N. Textural Alterations in Coal Fly Ash due to Alkali Activation. J. Mater. Civ. Eng. 2016, 28, 04016126. [CrossRef]

39. Wan, Q.; Rao, F.; Song, S.; García, R.E.; Estrella, R.M.; Patino, C.L.; Zhang, Y. Geopolymerization reaction, microstructure and simulation of metakaolin-based geopolymers at extended Si/Al ratios. Cem. Concr. Compos. 2017, 79, 45-52. [CrossRef]

40. Lee, B.; Kim, G.; Kim, R.; Cho, B.; Lee, S.; Chon, C.M. Strength development properties of geopolymer paste and mortar with respect to amorphous $\mathrm{Si} / \mathrm{Al}$ ratio of fly ash. Constr. Build. Mater. 2017, 151, 512-519. [CrossRef] 
41. Sore, S.O.; Messan, A.; Prud'homme, E.; Escadeillas, G.; Tsobnang, F. Synthesis and characterization of geopolymer binders based on local materials from Burkina Faso-Metakaolin and rice husk ash. Constr. Build. Mater. 2016, 124, 301-311. [CrossRef]

42. Feng, D.; Provis, J.L.; Van Deventer, J.S.J. Thermal activation of albite for the synthesis of one-part mix geopolymers. J. Am. Ceram. Soc. 2012, 95, 565-572. [CrossRef]

43. Zhang, J.; Li, C. Experimental Study on Lime and Fly Ash-Stabilized Sintered Red Mud in Road Base. J. Test. Eval. 2018, 46, 1539-1547. [CrossRef]

44. Park, Y.; Park, J.; Hinoki, T.; Kohyama, A. Thermal shock behavior of NITE-porous SiC ceramics. In Proceedings of the 31st International Conference on Advanced Ceramics and Composites, Daytona Beach, FL, USA, 21-26 January 2007; Brito, M., Case, E., Kriven, W.M., Eds.; pp. 89-94.

45. Steveson, M.; Sagoe-Crentsil, K. Relationships between composition, structure and strength of inorganic polymers: Part 2 Fly ash-derived inorganic polymers. J. Mater. Sci. 2005, 40, 4247-4259. [CrossRef]

(C) 2019 by the authors. Licensee MDPI, Basel, Switzerland. This article is an open access article distributed under the terms and conditions of the Creative Commons Attribution (CC BY) license (http://creativecommons.org/licenses/by/4.0/). 